\title{
Cultural sustainability and kindship mode of production AMIDST global economy
}

\author{
Levita Duhaylungsod \\ University of the Philippines, Los Banos, Philippines
}

\begin{abstract}
Global capitalism made possible the expansion of economic processes that spread to all parts of the world and transformed many regions into economic areas reigned by the principle of free market. ASEAN integration facilitated such process in the region and as a consequence political and state boundaries do not only become porous but also transforms people and communities into either consuming subjects or commodi- ties. Reviewing kinship mode of production as the characteristic nature of production systems of ASEAN communities, the paper argues for possible alternative production organizations and arrangements that are much more culturally attuned to traditional forms of economic life.

Keywords: communities, production organization, culturally
\end{abstract}

\section{INTRODUCTION}

Global capitalism made possible the expansion of economic processes that spread to all parts of the world and transformed many regions into economic areas reigned by the principle of free market. In the Southeast Asian region, the scope of market integration was predated by the creation of an ASEAN Free Trade Area (AFTA) that took effect in 2008 eventually resulting in the ASEAN Economic Community (AEC) characterized by a common market with free flow of goods, services and capital (Yoshimatsu 2007). It is the primary driving force that encour-aged the ASEAN integration project with the major premise of developing a stable, prosperous and competitive regional economic area.

The paper forwards an analytical lens anchored on cultural economies perspective focusing on an examination of the kinship mode of production characteristic of non-capitalist economic systems. While this analytical lens is not novel, it finds relevance in the current context of ASEAN integration with globalized economic processes. In resurrecting such analytical framework, the paper argues that it is possible to develop alternative production organizations and arrangements that are much more culturally attuned to traditional forms of economic life.
Prior to the increased market integration, many economic forms in the ASEAN communities are characterized by much culture-based transactions which anthropology referred to as cultural economies (Halperin 1994). With social and cultural spheres being overtaken by the logic of market, community solidarity and social cohesion that un- derpin much of the social exchanges and relation- ships of traditionbased production systems are fac- ing threats of breakdown.

\section{RESEARCH METHODS}

The study applied descriptive research method using primary data of interview with subjects from ASEAN Community, and observation as well as secondary data from articles, newspaper, data center, books, and website.

The field of Anthropology, in particular Economic Anthropology, distinguished two perspectives in economics: Formalism and Substantivism. The distinction was drawn from Polanyie s (1944) argument that formal economic theory applies only to industrial western societies where true market exchange exists. In contrast, exchange in non-industrial societies is very much embedded in kinship, religion and politics. Polanyiecs argument derives from the richness 
of ethnographies across a variety of cultures that have accumulated in his time. In particular, he drew from Mauss (1969) concept of gift, to further illustrate how transactions of goods in many traditional societies do not follow market ideology.

\section{RESULT AND DISCUSSIONS}

Polanyie ${ }^{\text {e }}$ distinction was a groundbreaking work in Economic Anthropology and the debate between Formalist and Substantivist schools became influential that shaped the field in that era. Concepts of gift, reciprocity and commodity exchanges, including classifications and spheres of exchanges, were developed and further refined and theorized by succeeding economic anthropologists (e.g. Sahlins 1972, Gregory 1982, Gudeman 1986, Strathern 1988, Bloch and Parry 1989, among others). In tracing the history of Economic Anthropology, Hann \& Hart (2011) captured the heyday of the formalist/substantivist debate in a whole chapter of their book and titled it as The Golden Age of Economic Anthropology (2011).

In later years, when the formalist/substantivist debates subsided, Gudeman (1986, 2001, 2008) persisted to further contribute to economic anthropology and shifted his analytical focus on the household economies and community, eventually getting identified as the representative of the culturalist approach to economics. Much more recently, he expanded his analytical frame by forwarding the notion of economic spheres with progression from household economies, community, commerce, finance and meta-finance (Gudeman 2016). The latter work demonstrates that the culture-based concepts of sharing and reciprocity become even more essential even in the kind of economy in contemporary times where there are bubbles and downturns.

Although a lesser figure in the field, Halperin $(1988,1994)$ is to be credited for producing two volumes that similarly took inspiration from Polanyiees work. What is distinct in her approach, particularly in the 1994 book, is the set of analytical concepts that serves as some kind of tool kit that allows researchers to "cross and criss-cross between differently organized economic processes: capitalist, precapitalist and noncapitalis processes that are organized by combinations of qualitatively different institutional arrangements" (Halperin 1994). By combining ecological and economic dimensions in her work, coupled with case studies, a cross-cultural comparison is made tenable with her approach that focuses on cultural systems and economic processes. In particular, two concepts are worth looking into that help illuminate economic production arrangements in many communities in the ASEAN region: informal economy and house holding.

As globalization advances and with increasing market integration of many communities in the ASEAN region, it is important to understand the dynamic interplay of culture-based economies and the profit, economic growth logic that these communities are confronted with. It is within this context that the paper reviews the nature of kinship mode of production generally characteristic of ASEAN communities in transition to, if not embracing, the mar- ket logic of production.

The rise of neoliberal globalization that intensified the encapsulation of many ASEAN communities into the market economy is a phenomenon that challenges social scientists, particularly anthropologists, to expand inquiries into the sociocultural impact of unabated market domination in the region. This phenomenon is not new analytic terrain for anthropology. However, contemporary social sciences have seen the "decolonization" of the academic enterprise which pose challenges to "native" academics to develop more ,self-conscious "ee disciplines. Yet, current Scopus bibliometric profile indicates that the ASEAN"s contribution in the social sciences is relatively smaller. It therefore behooves us to contribute to a more grounded understanding of our own societies and communities (Duhaylungsod 2017). This challenge does not imply that we abandon the Western constructed, intellectual legacy that much of the region "e academia embraced. We can build on it, especially when we find analytical strength in the wealth of knowledge accumulated from such lens and facilitate deeper understanding of our current sociocultural predicament. The concept of kinship mode of production that draws much inspiration from Wolf (1982) is one of those powerful concepts.

Subsistence-oriented communities do not produce in accordance with norms of maximization and expansion; rather, the level of production is usually in accordance to with the socially defined needs of the household. While there is truth in the lack of surplus that can serve as engine for a more profit-oriented logic of production, lost in this economistic, reductionist outlook is the system of social organization that serves as form of solidarity and community cohesion. These features of social organization are, invariably, characteristics of non-capitalist economies.

In virtually every ethnographic account of varied non-capitalist economies, economic patterns and processes are underpinned by culture-based arrangements that determine the production, distribution and exchange of goods and services. Such arrangements are usually not apparent to the casual 
observer, or, for that matter, a person whose general orientation is to economic and profit rationality that premises capitalist mode of production.

Noncapitalist systems differ from capitalist system in regard to the way production is organized and how resources are distributed and allocated. While it is true that all societies share common elements such as exchange, labor, resource use and allocation, formal economic theory is inappropriate to understand the complexity of the "economic" cultural constructs of noncapitalist systems. As Gudeman (1986) argues, all the elements of economic systems are cultural constructs and therefore analysis should begin with how locals organize their economic activities and behavior according to the general system of cultural values.

Central to the social organization of subsistence societies is kinship. Wolf (1982), noting its centrality in the textured anthropological accounts on these societies, coined the term ,kin-ordered ${ }^{\text {tee }}$, alongside „tributary", mode of production to distinguish such societies from the capitalist mode of production. Kinship defines the relationships into which people are placed which covers filiation, marriage, consanguinity, and affinity. In a kinship mode of production, social organization of labor deploys kinship relationships. In contrast, under capitalist mode, labor is mobilized through purchase and sale of labor power.

What is remarkable in Wolfes work is how he located this classification within a comprehensive historical context of Western capitalist expansion. His perspective veers away from an evolutionary treatment of types of economic production systems; instead, he presents the tension between the logic of production that informs non capitalist economies and the entry of market in such societies.

Non-market rationality and non-market organization generally characterize subsistence production which are also relatively small-scale. Production and distribution processes revolve around kinship groups and exchange processes involve barter, sharing and reciprocity transactions. Where there is a semblance of market, equivalencies of goods are developed depending upon the extent of resources and availability of supply which, in the process, entails qualitative dimensions. There are rituals for planting, gathering or harvesting, and overall, there is a sense of obligation to help and protect the circle of kin groups. Spirituality and religion are therefore very much intertwined within the production system, including social and community relations.

Communities are woven into a network of reciprocal relations that is carried on trans generationally and this is usually demonstrated in response to times of crises and scarcity. The concept of saving and accumulation carries no prestige because surplus, if at all, is flowed back to feasts and community celebrations. Competitive exchanges are levelled off with a strong normative system of social cohe- sion and solidarity (Duhaylungsod \& Hyndman 1995, Duhaylungsod 1998, 2000).

The concept of house holding is useful in examining the articulation of noncapitalist communities with market and capitalist mode of production. Drawing from Polanyiees (1944) work, house holding is the third principle in noncapitalist economies defined as "the practice of catering for the needs of one $\mathrm{s}$ household [that] becomes a feature of economic life only on a more advanced level of agriculture; however, even then it has nothing in common either with the motive of gain or with the institutions of markets".

In societies that are dominantly subsistenceoriented and market economy is already at play, house holding principle becomes the institutional ar-

rangement to provide the material means for the survival of the members of the group which is usually within kinship network. Halperin (1994) argues that house holding serves as a form of economic integration that "has the capacity to deal with complex economic processes, especially with the articulation of different institutional arrangements organizing units of production and consumption in stratified, statelevel societies- pre-industrial, industrial, and postindustrial." In some communities, house holding can be used as a strategy of self-sufficiency and autonomy. I have similarly argued elsewhere that house holding is a mechanism for the endurance and persistence of subsistence economies even amidst capitalist economies (Duhaylungsod 1998).

Many communities in the ASEAN region are characteristically rural where households find themselves at the crossroad of a monetized economy brought about by the expansion of capitalism intensified by the ASEAN integration project.

In many instances, the domestic, subsistence economy loses its autonomy and is stretched to engage in diverse petty or simple commodity production (e.g. vegetable or fruits selling, crafts or artisan goods, weaving etc.) as an economic engagement congruent with the household. Alongside, informal economies also find accommodation in these newly emerged markets where monetary transactions, exchanges and wage labor are in some kind of disguised wage work. The value of work-time is usually less than that of wage work as measured by the realized product (Harris 2010).

ASEAN communities, invariably operating on kinship mode of production, are caught up with the global reach of capitalist forces. Entrepreneurial types of production in emerging market economies 
in many areas in the region are usually Janus-faced. It represents a capitalist formation, yet in many instances, deployment of labor taps the kinship network and relations. Labor is commoditized but, at the same time, entrepreneurs can get around wage work rates by mining the ,fund of goodwill" in the kinship relationship. The value of house holding is also at play and family labor is a handy resource for entrepreneurial venture to feed market demands. Subsistence households are governed by safety-first principle and subsistence ethic, not profit. Using the villagers in Southeast Asia as case examples, Scott (1976) referred to this ethic as part of their „moral economy".

Global capitalism has the concomitant effects of social exclusion, fragmenting communities and, with its premium on individualism, breakdown of communal solidarity. The capitalist circuit of exchange disadvantages the noncapitalist sectors (kin-ordered) in both purchases of the latter"s products as commodities and their sale of labor power. This asymmetrical social relation of production has always been the historical pattern among traditional culture systems not just in the ASEAN region. The goal of surplus extraction and profit accumulation inherent in capitalism leads to overexploitation of labor power, including depletion of natural resources.

The totalizing tendency of market mechanism does not simply promote consumerism; even more significantly, it erodes traditions and communities and leads to social alienation where individuals are left to their own resources and acumen. In a comprehensive analysis of the patterns of impacts of the spread of Western capitalism across different societies and nation-states, Baumann (2010) observes that, as a consequence, individuals are forced "to devise individual solutions to socially generated problems, and to do it individually, using their own individual skills and individually possessed assets". In other words, the strength of household, family and community to provide social insurance for individual members of community is fundamentally diminished, if not totally lost.

The challenge posed to ASEAN is to develop blueprint for an alternative social organization that transcends capitalism. Globalization promotes a fast and sweeping modernization process but Baumann (2010) further argues that "the ability to modernize swiftly and with little damage to social cohesion and solidarity are not and need not be at loggerheads." Non-market social institutions, such as households, can be mobilized to protect labor and challenge its exploitation.

\section{CONCLUSION}

Globalization and ASEAN integration are irreversible processes that bring modernity and foster regional cooperation and exchange. At the same time, the processes result in different ways of adjustments and stages of development. There may be no readymade blueprint for alternative social organization but it is compelling for the region to promote mechanisms or policies that countervail the market-imposed division of labor and its rule on valuation. Drawing from the cultural richness of kin-ordered system of production and the social cohesion, solidarity and sense of community that such an economic system fostered, it is possible to embrace globalization that allows a socially equitable system and cultural sustainability.

\section{REFERENCES}

Baumann, Z., \& C. Rovirosa-Madrazo. 2010. Living on Borrowed Time. Cambridge, UK: Polity Press.

Bloch, M. \& Parry, J. (eds). 1989. Money and the Morality of Exchange. Cambridge, UK: Cambridge University Press.

Duhaylungsod \& Hyndman. 1995. Enduring Systems of Subsistence and Simple Reproduction in the Philippines. Pilipinas 25:21-48.

Duhaylungsod, L. 1998. Rethinking Subsistence through Cultural Economies of Indigenous Peoples. Diliman Review 4 (2):14-22.

Duhaylungsod, L. 2000. From Subsistence to Agricultural Intensification: Contradictions and Integration in the Changing Mode of Production of Indigenous Peoples. SEARCA Professorial Lecture delivered at the Department of Agricultural Education and Rural Studies (DAERS). July 2000.

Duhaylungsod, L. 2017. Will the ASEAN Ever Meet: Globalization and Challenges in Research Collaboration and Partnerships. Paper presented to the $60^{\text {th }}$ Anniversary of the University of Social Sciences and Humanities, Vietnam University. HoChiMinh: Vietnam.

Gregory C. 1982. Gifts and Commodities. London: Academic Press.

Gudeman, S. 1986. Economics as Culture: Models and Metaphors of Livelihood. London: Routledge and Kegan Paul.

Gudeman, S. 2001. The Anthropology of Economy: Community, Market and Culture. Malden, MA: Blackwell.

Gudeman, S. 2008. Economy's Tension: The Dialectics of Community and Market. Oxford: Berhgahn.

Gudeman, S. 2016. Anthropology and Economy. Part of New Departures in Anthropology. Cambridge: Cambridge University Press.

Halperin, R. 1988. Economies Across Cultures. London: Macmillan.

Halperin, R. 1994. Cultural Economies: Past and Present. Austin, USA: University of Texas Press.

Hann, C. \& Hart, K. 2011. Economic Anthropology: Higtory, Ethnography and Critique. Cambridge, UK: Polity Press. 
Harris, B. 2010. Capitalism and the Common Man. Lecture presented to the Annual Lecture, Graduate Institute, Geneva. Switzerland.

Mauss. M. 1925 (1969). The Gift: Forms and Functions of Exchange in Archaic Societies. London: Cohen and West.

Polanyi, K. 1944. The Great Transformation. New York: Holt, Rinehart and Wisnton.

Sahlins, M. 1972. Stone Age Economics: Chicago: Aldine.

Scott, J. 1976. The Moral Economy of the Peasant: Rebellion and Subsistence in Southeast Asia. New Haven, Conn.: Yale University Press.

Strathern, M. 1988. The Gender of the Gift: Problems with Women and Problems with Society in Melanesia. Berkely: University of California Press.

Wolf, E. 1982. Europe and the Peoples Without History. Berkely: University of California Press. 